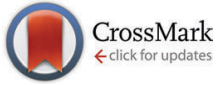

Cite this: Chem. Commun., 2015, 51, 1862

Received 30th October 2014, Accepted 8th December 2014

DOI: $10.1039 / c 4 c c 08606 f$

www.rsc.org/chemcomm

\section{Efficient photochemical water oxidation by a dinuclear molecular ruthenium complex $\dagger$}

\author{
Tanja M. Laine, Markus D. Kärkäs, * Rong-Zhen Liao, * Torbjörn Åkermark, \\ Bao-Lin Lee, Erik A. Karlsson, Per E. M. Siegbahn and Björn Åkermark*
}

\begin{abstract}
Herein is described the preparation of a dinuclear molecular Ru catalyst for $\mathrm{H}_{2} \mathrm{O}$ oxidation. The prepared catalyst mediates the photochemical oxidation of $\mathrm{H}_{2} \mathrm{O}$ with an efficiency comparable to state-of-the-art catalysts.
\end{abstract}

The development of sources of renewable energy is an increasingly acute problem for mankind. An attractive option would be to utilize solar energy but in order to use its full potential, means of storing it have to be developed. Solar driven splitting of $\mathrm{H}_{2} \mathrm{O}$ into $\mathrm{H}_{2}$ and $\mathrm{O}_{2}$ provides an attractive way of achieving this. However, this process is very intricate because it involves multi-electron transfer, extensive bond breaking and bond formation. In the splitting of $\mathrm{H}_{2} \mathrm{O}$, the stumbling block is the oxidation of $\mathrm{H}_{2} \mathrm{O}$ to generate molecular oxygen, electrons, and protons (eqn (1)). This is due to the fact that $\mathrm{H}_{2} \mathrm{O}$ oxidation involves strongly oxidizing intermediates which leads to decomposition of the catalysts. There is thus an urgent need to develop more robust and efficient water oxidation catalysts (WOCs). ${ }^{1}$

$$
2 \mathrm{H}_{2} \mathrm{O} \rightarrow \mathrm{O}_{2}+4 \mathrm{H}^{+}+4 \mathrm{e}^{-}
$$

During the past years a number of efficient Ru WOCs have been presented, both dinuclear ${ }^{2}$ and mononuclear. ${ }^{3}$ Much work has focused on mononuclear complexes because of the relative simplicity by which these complexes can be synthesized and mechanistically studied, thus aiding the development of improved WOCs. In addition to the widely developed Ru-based WOCs, earth-abundant metal WOCs based on $\mathrm{Mn},{ }^{4} \mathrm{Co},{ }^{5} \mathrm{Fe}^{6}$ and $\mathrm{Cu}^{7}$ have been reported.

The generation of ligands that can strongly bind and stabilize metal centers in high-valent oxidation states is of great

Department of Organic Chemistry, Arrhenius Laboratory, Stockholm University, SE-106 91 Stockholm, Sweden. E-mail: markusk@organ.su.se,

rongzhen@organ.su.se, bjorn.akermark@organ.su.se; Tel: +468163223

$\dagger$ Electronic supplementary information (ESI) available: Experimental details, NMR, electrochemistry, mass spectra and quantum chemical calculations details. See DOI: $10.1039 / \mathrm{c} 4 \mathrm{cc} 08606 \mathrm{f}$ interest. Thus far, the majority of the developed WOCs require a powerful sacrificial oxidant, such as $\mathrm{Ce}^{\mathrm{IV}}$, to drive $\mathrm{H}_{2} \mathrm{O}$ oxidation. However, a sustainable $\mathrm{H}_{2} \mathrm{O}$ splitting system needs a lightabsorbing photosensitizer that can be regenerated and is stable at neutral $\mathrm{pH}$. An appealing approach is to drive $\mathrm{H}_{2} \mathrm{O}$ oxidation with $\left[\mathrm{Ru}(\mathrm{bpy})_{3}\right]^{3+}$ type oxidants, which can be photogenerated from the well-studied $\left[\mathrm{Ru}(\mathrm{bpy})_{3}\right]^{2+}$-type complexes. ${ }^{8,9}$ This can be realized by lowering the redox potentials of the WOCs, by introducing anionic ligands into the ligand frameworks of the WOCs. . $^{3 f, g, 10,11}$

We have recently reported on such a ligand (1), which contains phenol and imidazole donor groups. ${ }^{12}$ However, reaction with $\mathrm{Ru}(\mathrm{DMSO})_{4} \mathrm{Cl}_{2}$ resulted in a dimeric $\mathrm{Ru}$ complex with a 1:1 ratio of $\mathrm{Ru}$ /ligand, instead of the anticipated dinuclear complex. Since this complex did indeed oxidize $\mathrm{H}_{2} \mathrm{O}$, using $\left[\mathrm{Ru}(\mathrm{bpy})_{3}\right]^{3+}$ as oxidant, we decided to prepare a more open ligand that could potentially give a dinuclear complex. Ligand 2, where the bridging phenol unit has been replaced by a pyrazole moiety provides such an open structure. As expected, coordination of two $\mathrm{Ru}$ centers yielded the dinuclear $\mathrm{Ru}$ complex 3 (Fig. 1 and 2). Herein, we show that the dinuclear $\mathrm{Ru}$ complex 3 catalyzes photochemical $\mathrm{H}_{2} \mathrm{O}$ oxidation with high activity, reaching turnover numbers (TONs; defined as produced moles of $\mathrm{O}_{2}$ per mole catalyst) of $\sim 900$, which is, to the best of our knowledge, among the highest obtained for a molecular catalyst in a single run. The observed high catalytic activity is ascribed to the ability of the designed ligand framework to stabilize the metal centers in high-valent redox states. This work thus highlights the importance of using negatively charged ligand scaffolds to carry out the oxidation of $\mathrm{H}_{2} \mathrm{O}$, which could be a general strategy for the design of future artificial WOCs with even higher catalytic efficiencies.

Ligand 2 was synthesized according to Scheme S1 (ESI $\dagger$ ), starting from commercially available 3,5-dimethyl pyrazole 4 . The dinuclear $\mathrm{Ru}_{2}{ }^{\mathrm{II}, \mathrm{III}}$ complex $3\left(\left[\left(\mathrm{H}_{2} \mathrm{~L}\right) \mathrm{Ru}_{2}{ }^{\mathrm{II}, \mathrm{III}}(\mathrm{pic})_{6}\right]\left(\mathrm{PF}_{6}\right)_{2}\right)$ was obtained by refluxing the $\mathrm{Ru}$ precursor $\left[\mathrm{Ru}(\mathrm{DMSO})_{4} \mathrm{Cl}_{2}\right]$ and ligand 2 followed by the addition of picoline. The structure of the dinuclear Ru complex 3 was supported by several methods, 


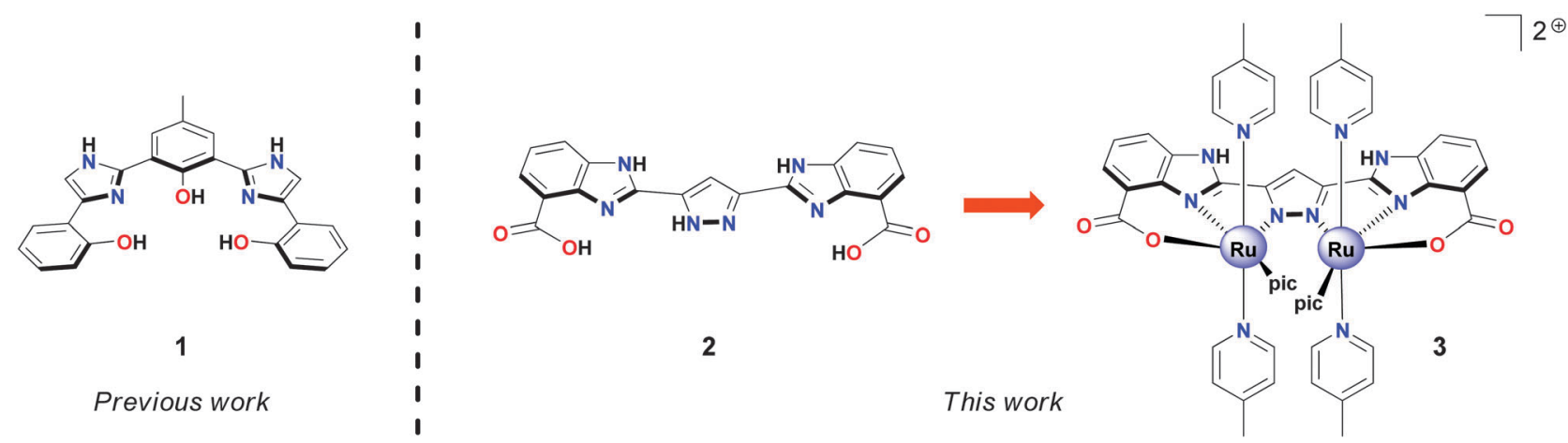

Fig. 1 Molecular structures of ligand 1, ligand $\mathbf{2}$ and the dinuclear Ru complex $\mathbf{3}$ (where pic = 4-picoline).

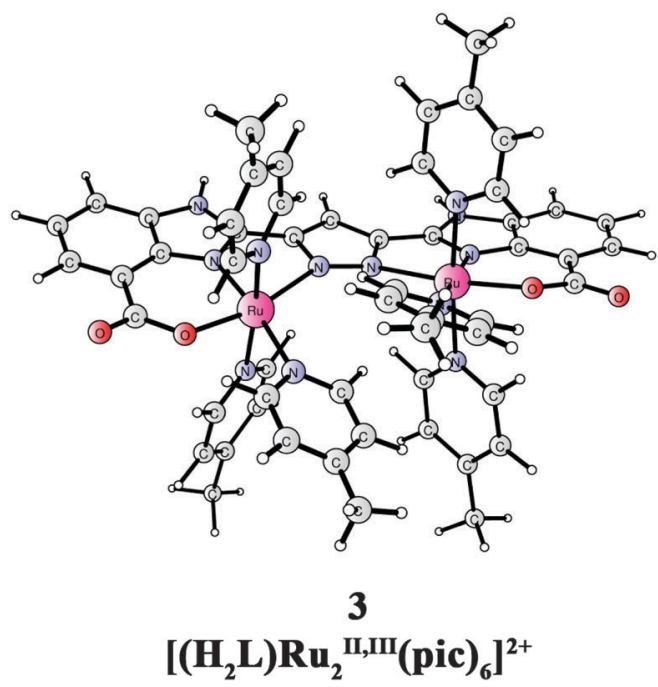

Fig. 2 Calculated structure of the dinuclear Ru complex $3\left(\left[\left(\mathrm{H}_{2} \mathrm{~L}\right) \mathrm{Ru}_{2}{ }^{11,111}(\text { pic })_{6}\right]^{2+}\right)$.

such as ${ }^{1} \mathrm{H}$ NMR, high-resolution mass spectrometry (HRMS), elemental analysis and electron paramagnetic resonance (EPR). Initial ${ }^{1} \mathrm{H}$ NMR experiments of Ru complex 3 only resulted in broad signals due to the paramagnetic nature of the $\mathrm{Ru}_{2}{ }^{\mathrm{II}, \mathrm{III}}$ complex 3. However, addition of a reductant, sodium dithionite $\left(\mathrm{Na}_{2} \mathrm{~S}_{2} \mathrm{O}_{4}\right)$, resulted in distinct signals, which supported the proposed structure of the developed complex. HRMS measurements of the complex in positive mode resulted in a peak with a characteristic isotope pattern at $m / z$ 1146.2155, which could be assigned to $\left[\left\{\left(\mathrm{H}_{2} \mathrm{~L}\right) \mathrm{Ru}_{2}{ }^{\mathrm{II}, \mathrm{III}}(\mathrm{pic})_{6}\right\}^{2+}-\mathrm{H}^{+}\right]^{+}\left(\left[3-\mathrm{H}^{+}\right]^{+}\right)$. The calculated structure of $\mathrm{Ru}$ complex 3 is depicted in Fig. 2. The electrochemistry of Ru complex $\mathbf{3}$ was subsequently studied by means of cyclic voltammetry (CV) and differential pulse voltammetry (DPV) in aqueous buffered solutions (phosphate buffer; $0.1 \mathrm{M}, \mathrm{pH}$ 7.2). From CV, a catalytic current corresponding to the electrochemical oxidation of $\mathrm{H}_{2} \mathrm{O}$ was observed with an onset potential of $\sim 1.20 \mathrm{~V} v s$. NHE, as shown in Fig. S19 (ESI $\dagger$ ). The DPV is depicted in Fig. S20 (ESI $\dagger$ ) and revealed several redox peaks, which were assigned to the formal redox processes $\mathrm{Ru}_{2}{ }^{\mathrm{II}, \mathrm{II}} \rightarrow \mathrm{Ru}_{2}{ }^{\mathrm{II}, \mathrm{III}} \rightarrow \mathrm{Ru}_{2}{ }^{\mathrm{III}, \mathrm{III}} \rightarrow \mathrm{Ru}_{2}{ }^{\mathrm{III}, \mathrm{IV}} \rightarrow$ $\mathrm{Ru}_{2}{ }^{\mathrm{IV}, \mathrm{IV}} \rightarrow \mathrm{Ru}_{2}{ }^{\mathrm{IV}, \mathrm{V}}$, where the latter state triggers $\mathrm{O}-\mathrm{O}$ bond formation. The electrochemistry was subsequently studied at pH 1 (Fig. S21-S24, ESI $\dagger$ ). Also here, several redox events were
Table 1 Catalytic data for the dinuclear Ru complex 3 in chemical and photochemical $\mathrm{H}_{2} \mathrm{O}$ oxidation

\begin{tabular}{|c|c|c|c|c|}
\hline \multirow[b]{2}{*}{ Concentration $[\mu \mathrm{M}]$} & \multicolumn{2}{|c|}{ Chemical oxidation $^{a}$} & \multicolumn{2}{|c|}{$\begin{array}{l}\text { Photochemical } \\
\text { oxidation }^{b}\end{array}$} \\
\hline & $\begin{array}{l}\text { pH } 7.2 \\
\text { TON }\left(\mathrm{TOF}^{c}\right)\end{array}$ & $\begin{array}{l}\text { pH } 6.2 \\
\text { TON }\left(\mathrm{TOF}^{c}\right)\end{array}$ & $\begin{array}{l}\mathrm{pH} 7.2 \\
\text { TON }\end{array}$ & $\begin{array}{l}\mathrm{pH} 6.2 \\
\text { TON }\end{array}$ \\
\hline 30 & - & - & 100 & - \\
\hline 3.0 & - & - & 500 & 890 \\
\hline 0.6 & $470(1.3)$ & $800(0.5)$ & - & - \\
\hline 0.3 & - & - & 830 & - \\
\hline
\end{tabular}

${ }^{a}$ Reaction conditions: an aqueous phosphate buffer solution $(0.1 \mathrm{M}$, $0.50 \mathrm{~mL})$ containing Ru complex $3(0.60 \mu \mathrm{M})$ was added to the oxidant $\left[\mathrm{Ru}\left(\mathrm{bpy}_{3}\right)\right]\left(\mathrm{PF}_{6}\right)_{3}(3.0 \mathrm{mg}, 3.0 \mu \mathrm{mol}) .{ }^{b}$ Reaction conditions: reactions were performed in an aqueous phosphate buffer solution $(0.1 \mathrm{M}$, $\mathrm{pH} 7.2,0.50 \mathrm{~mL}$ ) containing Ru complex 3 (the concentrations used are those that are indicated in the table), $\left[\mathrm{Ru}(\mathrm{bpy})_{2}(\mathrm{deeb})\right]\left(\mathrm{PF}_{6}\right)_{2}$ as photosensitizer $(0.60 \mathrm{mM})$ and $\mathrm{Na}_{2} \mathrm{~S}_{2} \mathrm{O}_{8}$ as sacrificial electron acceptor (23.5 mM). ${ }^{c}$ Turnover frequencies (TOFs) are given in $\mathrm{s}^{-1}$.

observed, suggesting that the dinuclear Ru complex 3 is able to accommodate a wide variety of redox states. From the electrochemical measurements it is clear that the use of ligand $2 \mathrm{in} \mathrm{Ru}$ complex 3 results in lowering of the redox potentials and stabilizes the $\mathrm{Ru}$ centers in high-valent states, suggesting that $\mathrm{H}_{2} \mathrm{O}$ oxidation can be driven by photogenerated $\left[\mathrm{Ru}(\mathrm{bpy})_{3}\right]^{3+}$-type complexes.

The activity of complex 3 was initially evaluated for $\mathrm{H}_{2} \mathrm{O}$ oxidation under neutral conditions, in an aqueous buffered solution $(0.1 \mathrm{M}, \mathrm{pH} 7.2)$, using pregenerated $\left[\mathrm{Ru}(\mathrm{bpy})_{3}\right]^{3+}$ as a mild one-electron chemical oxidant $\left(E_{1 / 2} \mathrm{Ru}^{\mathrm{II}} / \mathrm{Ru}^{\mathrm{II}}=1.26 \mathrm{~V} v s\right.$. NHE). The evolved gaseous products were monitored and quantified by real-time mass spectrometry (MS). Indeed, when an aqueous solution containing complex $\mathbf{3}$ was added to the $\left[\mathrm{Ru}(\mathrm{bpy})_{3}\right]^{3+}$ oxidant, $\mathrm{O}_{2}$ evolution was immediately triggered and resulted in high TONs and initial turnover frequencies (TOFs; defined as produced moles of $\mathrm{O}_{2}$ per mol catalyst per unit time) (Fig. S17, ESI $\dagger$ and Table 1). The source of the oxygen atoms in the evolved $\mathrm{O}_{2}$ was also studied, using isotopically labeled $\mathrm{H}_{2} \mathrm{O}\left(\mathrm{H}_{2}{ }^{18} \mathrm{O}\right)$, whereby the different isotopes ${ }^{18,18} \mathrm{O}_{2}$, ${ }^{16,18} \mathrm{O}_{2}$ and ${ }^{16,16} \mathrm{O}_{2}$ were measured in real-time with MS (Fig. S17, ESI $\dagger$ ). The ratio of the different $\mathrm{O}_{2}$ isotopes was in agreement with the calculated values, highlighting that $\mathrm{H}_{2} \mathrm{O}$ is the sole source of the two oxygen atoms in the evolved $\mathrm{O}_{2}$. 


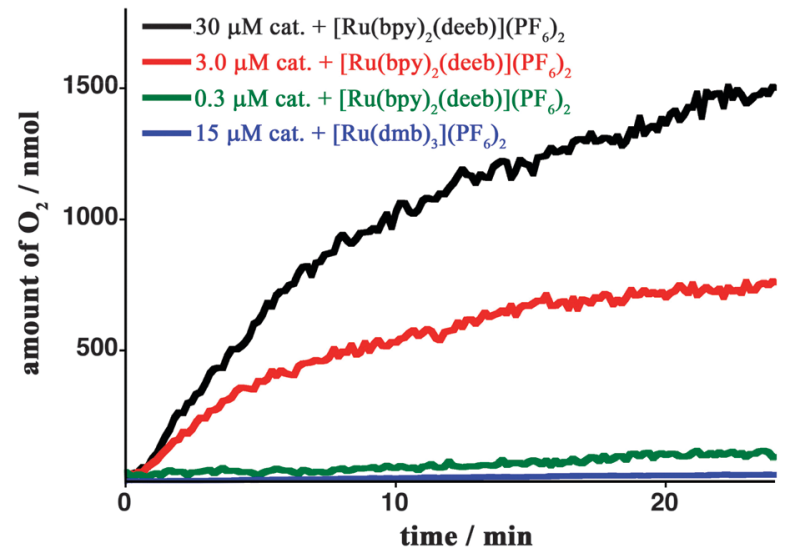

Fig. 3 Photochemical $\mathrm{H}_{2} \mathrm{O}$ oxidation catalyzed by dinuclear Ru complex 3 at different catalyst concentrations. Reaction conditions: reactions were performed in an aqueous phosphate buffer solution ( $0.1 \mathrm{M}, \mathrm{pH} 7.2,0.50 \mathrm{~mL})$ containing Ru complex 3, $\left[\mathrm{Ru}(\mathrm{bpy})_{2}(\mathrm{deeb})\right]\left(\mathrm{PF}_{6}\right)_{2}$ or $\left[\mathrm{Ru}(\mathrm{dmb})_{3}\right]\left(\mathrm{PF}_{6}\right)_{2}$ as photosensitizer $(0.60 \mathrm{mM})$ and $\mathrm{Na}_{2} \mathrm{~S}_{2} \mathrm{O}_{8}$ as sacrificial electron acceptor (23.5 mM).

An important question was now if Ru complex 3 was able to mediate photochemical $\mathrm{H}_{2} \mathrm{O}$ oxidation. The studied threecomponent catalytic system thus consisted of a $\left[\mathrm{Ru}(\mathrm{bpy})_{3}\right]^{2+}$ type complex as the light-absorbing component, sodium persulfate $\left(\mathrm{Na}_{2} \mathrm{~S}_{2} \mathrm{O}_{8}\right)$ as the sacrificial electron acceptor and $\mathrm{Ru}$ WOC 3. In the Initial experiments, the stronger photosensitizer $\left[\mathrm{Ru}(\mathrm{bpy})_{2}(\mathrm{deeb})\right]^{2+}\left(E_{1 / 2} \mathrm{Ru}^{\mathrm{III}} / \mathrm{Ru}^{\mathrm{II}}=1.40 \mathrm{~V} v s\right.$. $\mathrm{NHE}$; deeb $=$ diethyl (2,2'-bipyridine)-4,4'-dicarboxylate) was used in aqueous phosphate buffered solutions at $\mathrm{pH} 7.2$ (Fig. 3).

However, replacing the strong photosensitizer $\left[\mathrm{Ru}(\mathrm{bpy})_{2}\right.$ $(\mathrm{deeb})]^{2+}$ with the milder $\left[\mathrm{Ru}(\mathrm{bpy})_{3}\right]^{2+}$ photosensitizer strongly decreased the TON (not shown), which can perhaps be explained by the low thermodynamic driving force $\left(E_{1 / 2} \mathrm{Ru}^{\mathrm{III}} /\right.$ $\mathrm{Ru}^{\mathrm{II}}$ for $\left[\mathrm{Ru}(\mathrm{bpy})_{3}\right]=1.26 \mathrm{~V}$ and $E_{1 / 2}$ onset $=\sim 1.20 \mathrm{~V} v s$. NHE). To ensure that the reaction between the photosensitizer and persulfate is not an important source of $\mathrm{O}_{2}$ the even milder photosensitizer $\left[\mathrm{Ru}(\mathrm{dmb})_{3}\right]^{2+}\left(\mathrm{dmb}=4,4^{\prime}\right.$-dimethyl-2,2'-bipyridine $)$, which generates a $\mathrm{Ru}^{\mathrm{III}}$ complex with a redox potential of $1.10 \mathrm{~V} v s$. NHE, was also used. As was anticipated, this potential is insufficient for $\mathrm{H}_{2} \mathrm{O}$ oxidation and only traces of $\mathrm{O}_{2}$ were generated (Fig. 3).

It was therefore decided to continue using the stronger $\left[\mathrm{Ru}(\mathrm{bpy})_{2}(\mathrm{deeb})\right]^{2+}$ photosensitizer. Further experiments focused on studying the effect of $\mathrm{pH}$ on the catalytic $\mathrm{O}_{2}$ evolution activity since it was previously shown that the catalytic activity could be pH-dependent. ${ }^{13}$ The photochemical experiments were therefore performed at different $\mathrm{pH}$, under otherwise unchanged conditions (Fig. S18, ESI $\dagger$ ).

Carrying out the catalytic experiments at higher $\mathrm{pH}$ would intuitively be expected to result in a higher catalytic activity due to the higher driving force for $\mathrm{H}_{2} \mathrm{O}$ oxidation at this $\mathrm{pH}$. However, this was not what was observed. At pH 8.2, almost no activity at all was observed, most likely due to decomposition of the oxidized photosensitizer. Driving $\mathrm{H}_{2} \mathrm{O}$ oxidation at lower $\mathrm{pH}$ is hence associated with a lower driving force, however, it is believed that photosensitizer decomposition is reduced under these conditions. At $\mathrm{pH}$ 5.5, the lower driving force thus reduced the amounts of generated $\mathrm{O}_{2}$.

It could subsequently be shown that $\mathrm{pH} 6.2$ resulted in the best activity (Fig. S18, ESI $\dagger$ ). Performing the photochemical experiments at $\mathrm{pH} 6.2$ resulted in increased catalytic activity to reach an impressive TON of $\sim 900$ when using $\left[\mathrm{Ru}(\mathrm{bpy})_{2}(\mathrm{deeb})\right]^{2+}$ as photosensitizer (Fig. S18, ESI $\dagger$ and Table 1). It is believed that at $\mathrm{pH}$ 6.2, photosensitizer decomposition is reduced while still maintaining a relatively high driving force for carrying out $\mathrm{H}_{2} \mathrm{O}$ oxidation. These two beneficial effects thus give rise to the catalytic efficiency observed at $\mathrm{pH}$ 6.2. Collectively, this shows that complex 3 is an unusually efficient donor of electrons to the oxidized photosensitizer, thus resulting in high catalytic efficiency, and highlights the ability of the custom-synthesized ligand $\mathbf{2}$ to facilitate access to the required high-valent redox states.

To conclude, a novel dinuclear Ru complex based on ligand 2 has been synthesized. The ligand scaffold was designed to stabilize the $\mathrm{Ru}$ centers at high oxidation states, which is of importance in $\mathrm{H}_{2} \mathrm{O}$ oxidation catalysis. This approach was successful and resulted in an active WOC that could promote both chemical and photochemical $\mathrm{H}_{2} \mathrm{O}$ oxidation with mild oneelectron $\left[\mathrm{Ru}(\mathrm{bpy})_{3}\right]^{3+}$-type oxidants. In the photochemical system, the developed Ru complex 3 showed to be an efficient WOC and gave TONs comparable to state-of-the-art WOCs. Insight into the catalytic features associated with complex 3 revealed that the designed ligand architecture has an important role by stabilizing the metal centers in a variety of different redox states, which is of fundamental importance during the multi-electron oxidation of $\mathrm{H}_{2} \mathrm{O}$. This highlights that the engineering of WOCs comprised of anionic ligand scaffolds could be a general strategy for future construction of more efficient WOCs.

Financial support from the Knut and Alice Wallenberg Foundation, the Swedish Research Council, the Carl Trygger Foundation and the Swedish Energy Agency is gratefully acknowledged.

\section{Notes and references}

1 (a) M. D. Kärkäs, O. Verho, E. V. Johnston and B. Åkermark, Chem. Rev., 2014, DOI: 10.1021/cr400572f; (b) N. S. Lewis and D. G. Nocera, Proc. Natl. Acad. Sci. U. S. A., 2006, 103, 15729-15735; (c) M. D. Kärkäs, E. V. Johnston, O. Verho and B. Åkermark, Acc. Chem. Res., 2014, 47, 100-111.

2 (a) H.-W. Tseng, R. Zong, J. T. Muckerman and R. Thummel, Inorg. Chem., 2008, 47, 11763-11773; (b) X. Sala, I. Romero, M. Rodríguez, L. Escriche and A. Llobet, Angew. Chem., Int. Ed., 2009, 48, 2842-2852; (c) Y. Xu, T. Åkermark, V. Gyollai, D. Zou, L. Eriksson, L. Duan, B. Àkermark and L. Sun, Inorg. Chem., 2009, 48, 2717-2719; (d) Y. Xu, A. Fischer, L. Duan, L. Tong, E. Gabrielsson, B. Åkermark and L. Sun, Angew. Chem., Int. Ed., 2010, 49, 8934-8937.

3 (a) J. J. Concepcion, J. W. Jurss, J. L. Templeton and T. J. Meyer, J. Am. Chem. Soc., 2008, 130, 16462-16463; (b) X. Sala, M. Z. Ertem, L. Vigara, T. K. Todorova, W. Chen, R. C. Rocha, F. Aquilante, C. J. Cramer, L. Gagliardi and A. Llobet, Angew. Chem., Int. Ed., 2010, 49, 7745-7747; (c) D. J. Wasylenko, C. Ganesamoorthy, M. A. Henderson and C. P. Berlinguette, Inorg. Chem., 2011, 50, 3662-3672; (d) L. Duan, F. Bozoglian, S. Mandal, B. Stewart, T. Privalov, A. Llobet and L. Sun, Nat. Chem., 2012, 4, 418-423; (e) N. Kaveevivitchai, R. Zong, H.-W. Tseng, R. Chitta and R. P. Thummel, Inorg. Chem., 2012, 51, 2930-2939; $(f)$ M. D. Kärkäs, T. Åkermark, E. V. Johnston, S. R. Karim, T. M. Laine, B.-L. Lee, T. Åkermark, T. Privalov and B. Åkermark, Angew. Chem., Int. Ed., 
2012, 51, 11589-11593; $(g)$ M. D. Kärkäs, T. Åkermark, H. Chen, J. Sun and B. Åkermark, Angew. Chem., Int. Ed., 2013, 52, 4189-4193.

4 (a) J. Limburg, J. S. Vrettos, L. M. Liable-Sands, A. L. Rheingold, R. H. Crabtree and G. W. Brudvig, Science, 1999, 283, 1524-1527; (b) A. K. Poulsen, A. Rompel and C. J. McKenzie, Angew. Chem., Int. Ed., 2005, 44, 6916-6920; (c) E. A. Karlsson, B.-L. Lee, T. Åkermark, E. V. Johnston, M. D. Kärkäs, J. Sun, Ö. Hansson, J.-E. Bäckvall and B. Åkermark, Angew. Chem., Int. Ed., 2011, 50, 11715-11718; (d) E. A. Karlsson, B.-L. Lee, R.-Z. Liao, T. Åkermark, M. D. Kärkäs, V. Saavedra Becerril, P. E. M. Siegbahn, X. Zou, M. Abrahamsson and B. Åkermark, ChemPlusChem, 2014, 79, 936-950; (e) W. A. A. Arafa, M. D. Kärkäs, B.-L. Lee, T. Åkermark, R.-Z. Liao, H.-M. Berends, J. Messinger, P. E. M. Siegbahn and B. Åkermark, Phys. Chem. Chem. Phys., 2014, 16, 11950-11964.

5 (a) Q. Yin, J. M. Tan, C. Besson, Y. V. Geletii, D. G. Musaev, A. E. Kuznetsov, Z. Luo, K. I. Hardcastle and C. L. Hill, Science, 2010, 328, 342-345; (b) H. Lei, A. Han, F. Li, M. Zhang, Y. Han, P. Du, W. Lai and R. Cao, Phys. Chem. Chem. Phys., 2014, 16, 1883-1893.

6 (a) W. C. Ellis, N. D. McDaniel, S. Bernhard and T. J. Collins, J. Am. Chem. Soc., 2010, 132, 10990-10991; (b) J. Lloret Fillol, Z. Codolà,
I. Garcia-Bosch, L. Gómez, J. J. Pla and M. Costas, Nat. Chem., 2011, 3, 807-813.

7 (a) S. M. Barnett, K. I. Goldberg and J. M. Mayer, Nat. Chem., 2012, 4, 498-502; (b) Z. Chen and T. J. Meyer, Angew. Chem., Int. Ed., 2013, 52, 700-703.

8 A. Juris, V. Balzani, F. Barigelletti, S. Campagna, P. Belser and A. von Zelewsky, Coord. Chem. Rev., 1988, 84, 85-277.

9 J. M. R. Narayanam and C. R. J. Stephenson, Chem. Soc. Rev., 2011, 40, 102-113.

10 B.-L. Lee, M. D. Kärkäs, E. V. Johnston, A. K. Inge, L.-H. Tran, Y. Xu, Ö. Hansson, X. Zou and B. Åkermark, Eur. J. Inorg. Chem., 2010, 5462-5470.

11 T. Norrby, A. Börje, B. Åkermark, L. Hammarström, J. Alsins, K. Lashgari, R. Norrestam, J. Mårtensson and G. Stenhagen, Inorg. Chem., 1997, 36, 5850-5858.

12 M. D. Kärkäs, E. V. Johnston, E. A. Karlsson, B.-L. Lee, T. Åkermark, M. Shariatgorji, L. Ilag, Ö. Hansson, J.-E. Bäckvall and B. Åkermark, Chem. - Eur. J., 2011, 17, 7953-7959.

13 (a) Y. Xu, L. Duan, L. Tong, B. Åkermark and L. Sun, Chem. Commun., 2010, 46, 6506-6508; (b) T. Takashima, K. Hashimoto and R. Nakamura, J. Am. Chem. Soc., 2012, 134, 1519-1527. 